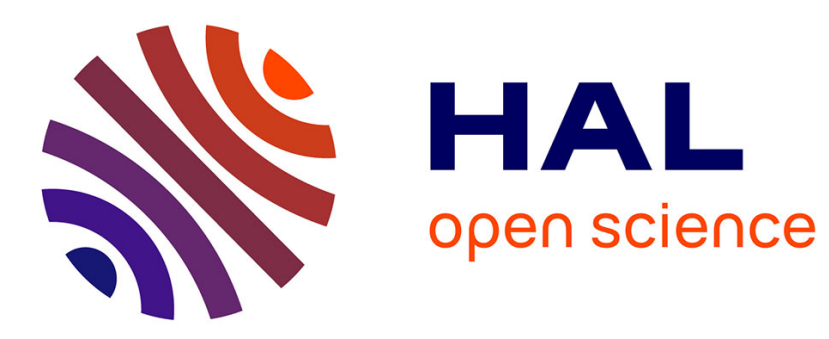

\title{
Stable lead(II) boroxides
}

Adrian-Alexandru Somesan, Erwann Le Coz, Thierry Roisnel, Cristian Silvestru, Yann Sarazin

\section{To cite this version:}

Adrian-Alexandru Somesan, Erwann Le Coz, Thierry Roisnel, Cristian Silvestru, Yann Sarazin. Stable lead(II) boroxides. Chemical Communications, 2018, 54 (42), pp.5299-5302. 10.1039/c8cc02459f . hal-01866167

\section{HAL Id: hal-01866167 https://hal-univ-rennes1.archives-ouvertes.fr/hal-01866167}

Submitted on 10 Dec 2021

HAL is a multi-disciplinary open access archive for the deposit and dissemination of scientific research documents, whether they are published or not. The documents may come from teaching and research institutions in France or abroad, or from public or private research centers.
L'archive ouverte pluridisciplinaire HAL, est destinée au dépôt et à la diffusion de documents scientifiques de niveau recherche, publiés ou non, émanant des établissements d'enseignement et de recherche français ou étrangers, des laboratoires publics ou privés. 


\section{ChemCommun}

\section{COMMUNICATION}

\section{Stable lead(II) boroxidest}

Received 00th January 20xx, Accepted 00th January 20xx

DOI: $10.1039 / \times 0 \times x 00000 x$

\section{www.rsc.org/}

The first examples of lead(II) boroxides, $\left[\mathrm{Pb}\left(\mathrm{OB}\left\{\mathrm{CH}\left(\mathrm{SiMe}_{3}\right)_{2}\right\}_{2}\right)_{2}\right]$ (1) and $\left[\left\{\mathrm{N}^{\wedge} \mathrm{C}\right\} \mathrm{PbOB}\left\{\mathrm{CH}\left(\mathrm{SiMe}_{3}\right)_{2}\right\}_{2}\right]\left(5 ; \mathrm{N}^{\wedge} \mathrm{C}=2-\mathrm{Me}_{2} \mathrm{NCH}_{2} \mathrm{C}_{6} \mathrm{H}_{4}\right)$, were prepared via simple protocols. These structurally characterised compounds are stable and, unlike lead(II) alkoxides and siloxides, do not trigger uncontrolled formation of lead(II) oxoclusters.

Lead(II) alkoxides $\left[\mathrm{Pb}(\mathrm{OR})_{2}\right]_{n}$ are excellent precursors to leadcontaining metal oxide materials such as glasses, ${ }^{1}$ but they are infamously tedious to prepare. They are often poorly soluble, and show tremendous propensity to form oxoclusters such as $\left[\mathrm{Pb}_{4}\left(\mu^{4}-\mathrm{O}\right)\left(\mu^{2}-\mathrm{OR}\right)_{6}\right]$ and $\left[\mathrm{Pb}_{6}\left(\mu^{3}-\mathrm{O}\right)_{4}\left(\mu^{3}-\mathrm{OR}\right)_{4}\right]$. This has been said to result from the release of dialkyl ethers $\mathrm{R}_{2} \mathrm{O}$ upon heating, ${ }^{2}$ from decomposition in the presence of moisture or other impurities, ${ }^{3}$ or from release of isobutene and $\mathrm{ROH}$ upon action of $\mathrm{HN}\left(\mathrm{SiMe}_{3}\right)_{2}$ or metal amides. ${ }^{4}$ Structurally authenticated lead(II) alkoxides have for long been limited to the trinuclear $\left.\left[\mathrm{Pb}_{3}\left(\mu^{2}-\mathrm{O}^{\mathrm{t}} \mathrm{Bu}\right)\right\}_{6}\right]$ and to polymeric $\left[\mathrm{Pb}\left(\mu^{2}-\mathrm{O}^{\mathrm{i}} \mathrm{Pr}\right)_{2}\right]_{\propto}$ and $\left[\mathrm{Pb}\left(\eta^{1}, \mu^{2}-\mathrm{OCH}_{2} \mathrm{CH}_{2} \mathrm{OMe}\right)_{2}\right]_{\propto}{ }^{3,5}$ Of late, dinuclear mixed alkoxo/amido $\quad\left[\mathrm{Pb}\left(\mathrm{N}\left(\mathrm{SiMe}_{3}\right)_{2}\right)\left(\mu^{2}-\mathrm{O}^{\mathrm{i}} \mathrm{Pr}\right)\right]_{2} \quad$ and $\left[\mathrm{Pb}\left(\mathrm{N}\left(\mathrm{SiMe}_{3}\right)_{2}\right)\left(\eta^{1}, \mu^{2}-\mathrm{O}^{\wedge} \mathrm{Se}^{\wedge} \mathrm{N}\right)\right]_{2}$ have been reported, ${ }^{5,6}$ while a handful of heteroleptic, mononuclear complexes [\{BDI\}Pb(OR)] supported by bulky $\beta$-diketiminato ligands have also been disclosed. $^{7}$

This paucity is even more pronounced for lead(II) siloxides. The attempted formation of $\left[\mathrm{Pb}\left(\mathrm{OSiPh}_{3}\right)_{2}\right]_{n}$ either from $\left[\mathrm{Cp}_{2} \mathrm{~Pb}\right]$ or $\left[\mathrm{Pb}\left(\mathrm{N}\left(\mathrm{SiMe}_{3}\right)_{2}\right)_{2}\right]$ has been repeatedly shown to return the oxocluster $\left[\mathrm{Pb}_{4}\left(\mu^{4}-\mathrm{O}\right)\left(\mu^{2}-\mathrm{OSiPh}_{3}\right)_{6}\right] .^{8}$ Thus, $\left[\mathrm{Pb}(\mathrm{OSiR})_{2}\right]_{n}$ species remain unauthenticated to this day, ${ }^{9}$ even though the heteroleptic $\left[\mathrm{Pb}\left(\mathrm{N}\left(\mathrm{SiMe}_{3}\right)_{2}\right)\left(\mu^{2}-\mathrm{OSiMe}_{3}\right)\right]_{2}$ was obtained by reaction of $\left[\mathrm{Pb}\left(\mathrm{N}\left(\mathrm{SiMe}_{3}\right)_{2}\right)_{2}\right]$ with ${ }^{\mathrm{t}} \mathrm{BuNCO} ;{ }^{10}$ the attempted synthesis of $\left[\mathrm{Pb}\left(\mathrm{OSiMe}_{3}\right)_{2}\right]_{n}$ following the same method only yielded the oxocluster $\left[\mathrm{Pb}_{7}\left(\mu^{3}-\mathrm{O}\right)\left(\mu^{4}-\mathrm{O}\right)\left(\mu^{2}-\mathrm{OSiMe}_{3}\right)_{10}\right]$ upon elimination of $\mathrm{Me}_{3} \mathrm{SiOSiMe}_{3}$.

Our attention was recently drawn to the fact that borinic acids $\mathrm{R}_{2} \mathrm{BOH}$ have never been implemented in lead chemistry, ${ }^{11}$ although boroxides exist for a variety of other main group metals, e.g. lithium, ${ }^{12}$ magnesium, ${ }^{12 d}$ zinc, $^{12 d, 13}$ cadmium, ${ }^{13 a}$ and aluminium. ${ }^{14}$ Boroxides $\mathrm{R}_{2} \mathrm{BO}^{-}$can be seen as electron poor versions of alkoxides, due to delocalisation of the $O$-atom lone pairs in the empty $p_{z}$ orbital at boron. We reasoned that this consideration, combined with its considerable steric demands, should render the boroxide $\left(\mathrm{Me}_{3} \mathrm{Si}\right)_{2} \mathrm{BO}^{-}$a suitable candidate to alleviate the tendency of regular alkoxides to form lead(II) clusters, and therefore could fill the existing loophole in lead(II) chemistry. We report here on the first lead(II) boroxides (and a tin(II) congener), which show superior stability with respect to other alkoxides.

\footnotetext{
a. Supramolecular Organic and Organometallic Chemistry Centre, Chemistry Department, Faculty of Chemistry and Chemical Engineering, Babes-Bolyai University, RO-400028 Cluj-Napoca, Romania. E-mail: cristian.silvestru@ubbcluj.ro; Tel: (+40) 264-593833. Univ Rennes, CNRS, ISCR (Institut des Sciences Chimiques de Rennes) - UMR 6226, F-35000 Rennes, France.

E-mail: yann.sarazin@univ-rennes1.fr; Tel: (+33) 223233019.

† Electronic Supplementary Information (ESI) available: Synthetic details; NMR and crystallographic data. See DOI: 10.1039/x0xx00000x
}

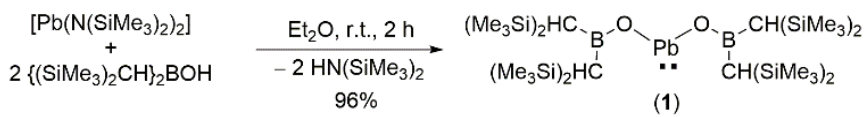

Scheme 1 Synthesis of $\left[\mathrm{Pb}\left(\mathrm{OB}\left\{\mathrm{CH}\left(\mathrm{SiMe}_{3}\right)_{2}\right\}_{2}\right)_{2}\right](\mathbf{1})$ 


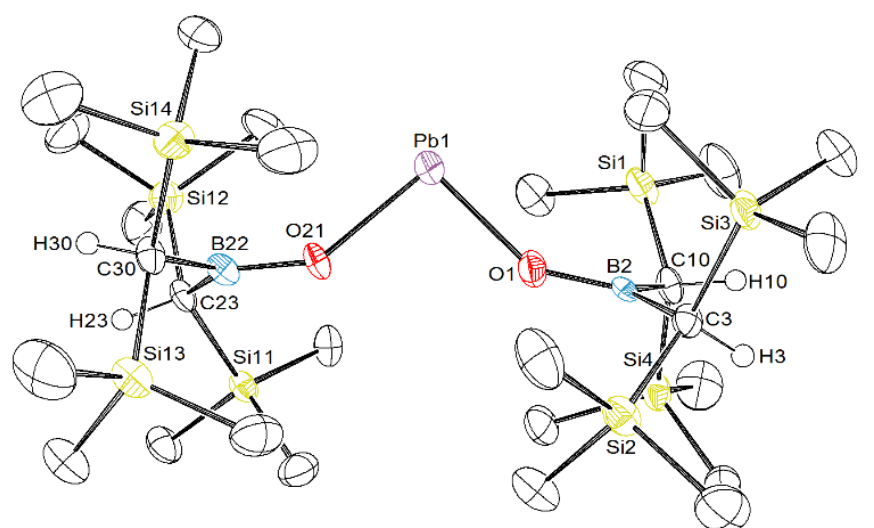

Fig. 1 ORTEP representation of the solid state structure of $\left[\mathrm{Pb}\left(\mathrm{OB}\left\{\mathrm{CH}\left(\mathrm{SiMe}_{3}\right)_{2}\right\}_{2}\right)_{2}\right](\mathbf{1})$ Ellipsoids drawn at the $50 \%$ probability level. All methyl $\mathrm{H}$ atoms omitted for clarity. Selected interatomic distances $(\AA)$ : $\mathrm{Pb} 1-01=2.067(6), \mathrm{Pb} 1-021=2.089(5), 01-\mathrm{B} 2=$ $1.356(10), \mathrm{B} 2-\mathrm{C} 3=1.573(12), \mathrm{B} 2-\mathrm{C} 10=1.584(13), \mathrm{O} 21-\mathrm{B} 22=1.353(10), \mathrm{B} 22-\mathrm{C} 23=$ $1.590(11), \mathrm{B} 22-\mathrm{C} 30=1.591(12)$. Selected angles $\left({ }^{\circ}\right):$ O1-Pb1-O21 $=95.60(2)$, $\mathrm{B} 2-\mathrm{O} 1-\mathrm{Pb} 1=147.90(5), \mathrm{B} 22-021-\mathrm{Pb} 1=145.10(5)$

We met in the past little difficulty in preparing and handling the known alkoxides $\left[\mathrm{Pb}\left(\mu^{2}-\mathrm{O}^{\mathrm{i}} \mathrm{Pr}\right)_{2}\right]_{\propto}$ and $\left[\mathrm{Pb}_{3}\left(\mu^{2}-\right.\right.$ $\left.\left.\left.\mathrm{O}^{\mathrm{t}} \mathrm{Bu}\right)\right\}_{6}\right] .{ }^{5}$ Yet, all attempts at synthesising the related siloxide $\left[\mathrm{Pb}\left(\mathrm{OSiPh}_{3}\right)_{2}\right]_{n}$ only yielded the known oxocluster $\left[\mathrm{Pb}_{4}\left(\mu^{4}-\right.\right.$ O) $\left.\left(\mu^{2}-\mathrm{OSiPh}_{3}\right)_{6}\right]$. We anticipated that the bulky borinic acid $\left\{\left(\mathrm{Me}_{3} \mathrm{Si}\right)_{2} \mathrm{CH}_{2} \mathrm{BOH}^{15}\right.$ should provide steric protection to the metal centre (and yield soluble complexes), despite a greater distance between the cumbersome alkyl groups and the metal centre with respect to conventional alkoxides. Treatment in $\mathrm{Et}_{2} \mathrm{O}$ of freshly distilled $\left[\mathrm{Pb}\left(\mathrm{N}\left(\mathrm{SiMe}_{3}\right)_{2}\right)_{2}\right]^{16}$ with 2 equivalents of $\left\{\left(\mathrm{Me}_{3} \mathrm{Si}\right)_{2} \mathrm{CH}\right\}_{2} \mathrm{BOH}$ at room temperature for $2 \mathrm{~h}$ afforded the bis-boroxide complex $\left[\mathrm{Pb}\left(\mathrm{OB}\left\{\mathrm{CH}\left(\mathrm{SiMe}_{3}\right)_{2}\right\}_{2}\right)_{2}\right]$ (1) upon clean elimination of $\mathrm{HN}\left(\mathrm{SiMe}_{3}\right)_{2}$ (Scheme 1). It was isolated in nearquantitative yield as a very pale yellow, air-sensitive solid upon removal of the volatiles. Its composition was formulated on the basis of spectroscopic and crystallographic data. It is very soluble in common organic solvents, including aromatic and aliphatic hydrocarbons. Complex $\mathbf{1}$ is the first occurrence of a lead(II) boroxide. ${ }^{11}$

The molecular structure of $\mathbf{1}$ was established by X-ray diffraction analysis of single crystals grown from pentane at $-40{ }^{\circ} \mathrm{C}$. The complex exists as a monometallic species in the solid state, with a two-coordinate metal centre (Fig. 1). The $\mathrm{Pb} 1-\mathrm{O} 1$ and $\mathrm{Pb} 1-021$ interatomic distances of 2.067(6) and 2.089(5) $\AA$ are remarkably short. They are for instance substantially larger in the bis-alkoxo complexes $\left[\mathrm{Pb}\left(\mu^{2}-\mathrm{O}^{\mathrm{i}} \mathrm{Pr}\right)_{2}\right]_{\propto}$ $(2.210(3)-2.522(2) \AA)^{5}$ and in $\left.\left[\mathrm{Pb}_{3}\left(\mu^{2}-\mathrm{O}^{\mathrm{t}} \mathrm{Bu}\right)\right\}_{6}\right](2.17(1)-2.55(1)$ $\AA),{ }^{3}$ in the amido-alkoxide $\left[\mathrm{Pb}\left(\mathrm{N}\left(\mathrm{SiMe}_{3}\right)_{2}\right)\left(\mu^{2}-\mathrm{O}^{\mathrm{i}} \mathrm{Pr}\right)\right]_{2}$ (2.289(9) $\AA)^{5}$ and in the amido-siloxide $\left[\mathrm{Pb}\left(\mathrm{N}\left(\mathrm{SiMe}_{3}\right)_{2}\right)\left(\mu^{2}-\mathrm{OSiMe}_{3}\right)\right]_{2}$ (2.276(8)-2.291(8) A). ${ }^{10}$ The O1-Pb1-O21 angle of $95.60(2)^{\circ}$ is close to the ideal value of $90^{\circ}$ expected for lead(II), testifying to a mostly $6 s^{2}$ lone pair of electrons with a minimal contribution of the empty $6 p_{z}$ orbital to the formation of an hybrid orbital. The geometry about the boron atoms is trigonal planar $\left(\Sigma_{\theta}(\mathrm{B} 2)=360.0^{\circ}\right.$ and $\left.\Sigma_{\theta}(\mathrm{B} 22)=359.9^{\circ}\right)$. The B2-O1-Pb1 and $\mathrm{B} 22-\mathrm{O} 21-\mathrm{Pb} 1$ angles of $147.90(5)$ and $145.10(5)^{\circ}$ suggest only small $\pi$-contributions to the $\mathrm{O} 1-\mathrm{Pb} 1$ and $\mathrm{O} 21-\mathrm{Pb} 1$ bonds The O1-B2 and O21-B22 distances (1.356(10) and 1.353(10) A) are only slightly shortened compared to that in the parent borinic acid (1.3805(17) Å).

The NMR spectroscopic data for $\mathbf{1}$ were recorded in $\mathrm{C}_{6} \mathrm{D}_{6}$.

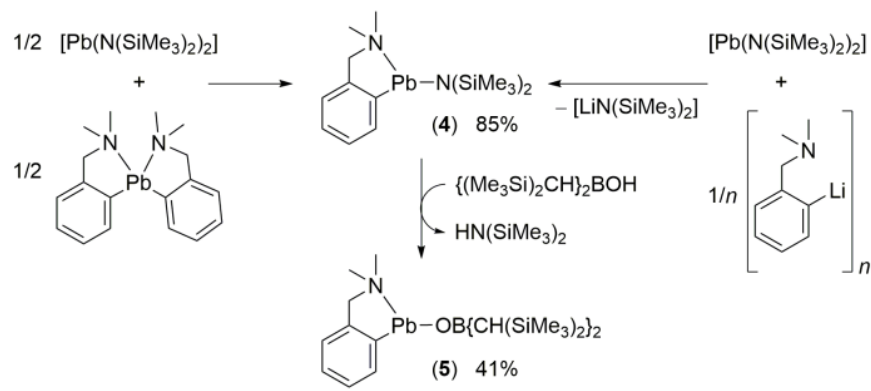

The ${ }^{1} \mathrm{H},{ }^{13} \mathrm{C}\left\{{ }^{1} \mathrm{H}\right\}$ and ${ }^{29} \mathrm{Si}$ spectra are unremarkable (see the Electronic Supporting Information). In the ${ }^{11} \mathrm{~B}$ NMR spectrum, a single, well-defined resonance is detected at $53.5 \mathrm{ppm}$, i.e. very close to the resonance seen for $\left\{\left(\mathrm{Me}_{3} \mathrm{Si}\right)_{2} \mathrm{CH}\right\}_{2} \mathrm{BOH}$ in the same solvent $\left(\delta_{11 \mathrm{~B}}=53.3 \mathrm{ppm}\right)$. In its ${ }^{207} \mathrm{~Pb} \mathrm{NMR}$ spectrum, 1 gives rise to a very sharp resonance at $1805 \mathrm{ppm}$. It is located at much higher field than that for the two-coordinate precursor $\left[\mathrm{Pb}\left(\mathrm{N}\left(\mathrm{SiMe}_{3}\right)_{2}\right]\left(\delta_{207 \mathrm{pb}}=4916 \mathrm{ppm}\right)\right.$, and it is also shielded compared to $\left[\mathrm{Pb}\left(\mathrm{N}\left(\mathrm{SiMe}_{3}\right)_{2}\right)\left(\mu^{2}-\mathrm{OSiMe}_{3}\right)\right]_{2} \quad\left(\delta_{207 \mathrm{~Pb}}=\right.$ $2443 \mathrm{ppm})^{10}$ and $\left[\mathrm{Pb}\left(\mathrm{N}\left(\mathrm{SiMe}_{3}\right)_{2}\right)\left(\mu^{2}-\mathrm{O}^{\mathrm{i}} \mathrm{Pr}\right)\right]_{2} \quad\left(\delta_{207 \mathrm{~Pb}}=2531\right.$ $\mathrm{ppm}){ }^{5}$ the ${ }^{207} \mathrm{~Pb}$ NMR data for $\left[\mathrm{Pb}\left(\mu^{2}-\mathrm{O}^{\mathrm{i}} \mathrm{Pr}\right)_{2}\right]_{\propto}$ and $\left[\mathrm{Pb}_{3}\left(\mu^{2}-\right.\right.$ $\left.\left.\mathrm{O}^{\mathrm{t}} \mathrm{Bu}\right)\right\}_{6}$ ] were not reported in Buhro's seminal papers. ${ }^{3,5}$ Chemical shifts in ${ }^{207} \mathrm{~Pb}$ NMR do not necessarily vary in line with the electron withdrawing/donating abilities of the substituents on the metal. Instead, the overall isotropic shielding it is a composite of the diamagnetic shielding $\left(\sigma_{D}\right)$, the paramagnetic shielding $\left(\sigma_{p}\right)$ and the spin-orbit shielding $\left(\sigma_{\mathrm{so}}\right)$. Without deconvolution of these contributions by DFT methods, ${ }^{17}$ and in view of the different coordination environments in the above compounds, we are refraining from unsound interpretation of ${ }^{207} \mathrm{~Pb}$ chemical shifts.

The congeneric tin(II) complex $\left[\mathrm{Sn}\left(\mathrm{OB}\left\{\mathrm{CH}\left(\mathrm{SiMe}_{3}\right)_{2}\right\}_{2}\right)_{2}\right]$ (2) was obtained in similar fashion in $82 \%$ yield upon stoichiometric reaction of $\left[\mathrm{Sn}\left(\mathrm{N}\left(\mathrm{SiMe}_{3}\right)_{2}\right)_{2}\right]$ and $\left\{\left(\mathrm{Me}_{3} \mathrm{Si}\right)_{2} \mathrm{CH}\right\}_{2} \mathrm{BOH}$. It also crystallised as colourless plates, and its molecular structure is isomorphous with that of $\mathbf{1}$ (ESI).

The preparation of a stable, monometallic, bisalkoxide-like lead(II) complex $\left[\mathrm{Pb}(\mathrm{OR})_{2}\right]$ is for now restricted to the above example with utilisation of the cumbersome boroxide $\left\{\left(\mathrm{Me}_{3} \mathrm{Si}\right)_{2} \mathrm{CH}\right\}_{2} \mathrm{BO}^{-}$. We also attempted to prepare a base-free $\left[\mathrm{Pb}\left(\mathrm{OCH}\left(\mathrm{CF}_{3}\right)_{2}\right)_{2}\right]$ bearing two electron-poor fluoroalkoxides by action of $\left(\mathrm{CF}_{3}\right)_{2} \mathrm{CHOH}$ onto $\left[\mathrm{Pb}\left(\mathrm{N}\left(\mathrm{SiMe}_{3}\right)_{2}\right)_{2}\right]$, but it only returned the oxocluster $\left[\mathrm{Pb}_{4}\left(\mu^{4}-\mathrm{O}\right)\left(\mu^{2}-\mathrm{OCH}\left(\mathrm{CF}_{3}\right)_{2}\right)_{5}\left(\mu^{3}-\right.\right.$ $\left.\mathrm{OCH}\left(\mathrm{CF}_{3}\right)_{2}\right)$ ] (3). Prior to this, the dimethylaminopyridine adduct $\left[\mathrm{Pb}\left(\mu^{2}-\mathrm{OCH}\left(\mathrm{CF}_{3}\right)_{2}\right)\left(\mathrm{OCH}\left(\mathrm{CF}_{3}\right)_{2}\right)(\mathrm{DMAP})\right]_{2}$ and the salt $\left[\mathrm{Me}_{2} \mathrm{NH}_{2}\right]_{2}\left[\mathrm{~Pb}_{2}\left(\mu^{2}-\mathrm{OCH}\left(\mathrm{CF}_{3}\right)_{2}\right)_{2}\left(\mathrm{OCH}\left(\mathrm{CF}_{3}\right)_{2}\right)_{4}\right],{ }^{18}$ as well as the complex $\left[\mathrm{Li}_{2} \mathrm{~Pb}_{2}\left(\mu^{2}-\mathrm{OCH}\left(\mathrm{CF}_{3}\right)_{2}\right)_{4}\left(\mu^{3}-\mathrm{OCH}\left(\mathrm{CF}_{3}\right)_{2}\right)_{2}\right],{ }^{19}$ were reported. Although it compares to the adamantane-like $\left[\mathrm{Pb}_{4}\left(\mu^{4}-\mathrm{O}\right)\left(\mu^{2}-\mathrm{OSiPh}_{3}\right)_{6}\right]^{8}$ and $\left.\left[\mathrm{Pb}_{4}\left(\mu^{4}-\mathrm{O}\right)\left(\mu^{2}-\mathrm{O}^{\mathrm{t}} \mathrm{Bu}\right)_{6}\right]\right]^{2,20}$ the molecular solid state structure of $\mathbf{3}$ differ from those of these compounds; its $\mathrm{Pb}_{4} \mathrm{O}_{7}$ core features $\mathrm{C}_{5}$ symmetry (ESI). Crystals of $\mathbf{3}$ were characterised by multinuclear NMR spectroscopy. 
Notably, a resonance at $693 \mathrm{ppm}$ is detected in its ${ }^{207} \mathrm{~Pb}$ NMR

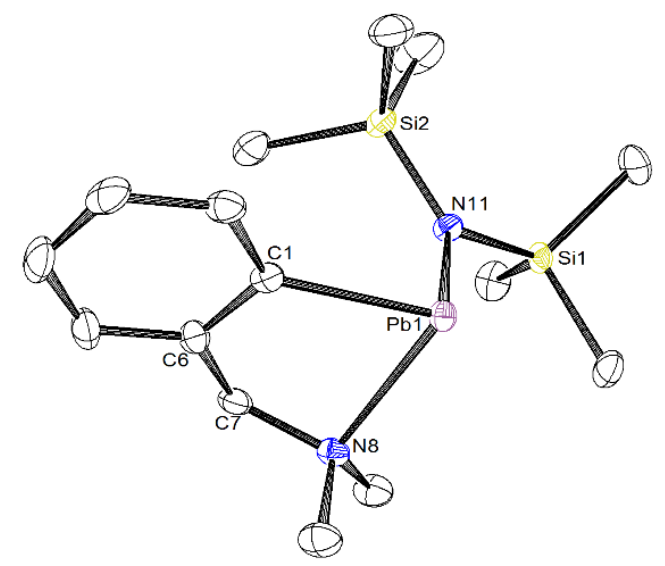

Fig. 2 ORTEP representation of the solid state structure of $\left[\left\{\mathrm{N}^{\wedge} \mathrm{C}\right\} \mathrm{PbN}\left(\mathrm{SiMe}_{3}\right)_{2}\right]$ (4) Ellipsoids drawn at the $50 \%$ probability level. $\mathrm{H}$ atoms omitted for clarity. Selected Scheme 2 Synt $\left.\left.\right|^{\text {interatomic distances }(\AA ̊)}\right): \mathrm{Pb} 1-\mathrm{N} 11=2.249(3), \mathrm{Pb} 1-\mathrm{C} 1=2.308(4), \mathrm{Pb} 1-\mathrm{N} 8=2.490(3)$.
$\left[\left\{\mathrm{N}^{\wedge} \mathrm{C}\right\} \mathrm{PbOB}\left\{\mathrm{Cr}^{\text {Selected angles }}\left({ }^{\circ}\right): \mathrm{N} 11-\mathrm{Pb} 1-\mathrm{C} 1=99.02(12), \mathrm{N} 11-\mathrm{Pb} 1-\mathrm{N} 8=94.18(11), \mathrm{C} 1-\mathrm{Pb} 1-\mathrm{N} 8=\right.\right.$ 73.25(12).

spectrum.

The synthesis of lead(II)-boroxides can be extended to the production of heteroleptic complexes. The bidentate, monoanionic ligand 2- $\mathrm{Me}_{2} \mathrm{NCH}_{2} \mathrm{C}_{6} \mathrm{H}_{4}^{-}\left(\right.$aka $\left\{\mathrm{N}^{\wedge} \mathrm{C}\right\}^{-}$) sharing 3 electrons lends itself well to the organometallic chemistry of lead(II), owing to the propensity of the ion $\mathrm{Pb}^{2+}$ to form 3 coordinate, 18-electron complexes. The amido precursor $\left[\left\{\mathrm{N}^{\wedge} \mathrm{C}\right\} \mathrm{PbN}\left(\mathrm{SiMe}_{3}\right)_{2}\right](4)$ was obtained in $85 \%$ isolated yield by mixing equimolar quantities of $\left[\mathrm{Pb}\left(\mathrm{N}\left(\mathrm{SiMe}_{3}\right)_{2}\right)_{2}\right]$ and $\left[\left\{\mathrm{N}^{\wedge} \mathrm{C}\right\}_{2} \mathrm{~Pb}\right] .^{21}$ It can also be prepared by reaction between $\left[\mathrm{Pb}\left(\mathrm{N}\left(\mathrm{SiMe}_{3}\right)_{2}\right)_{2}\right]$ and $1 / n$ equivalent of $\left[\left(\mathrm{N}^{\wedge} \mathrm{C}\right\} \mathrm{Li}\right]_{n}$ following elimination of [ $\left.\mathrm{LiN}\left(\mathrm{SiMe}_{3}\right)_{2}\right]$ (Scheme 2 ), although in this case separation from this by-product can be tedious. Complex $\mathbf{4}$ is a very rare case of low coordinate organolead(II) amide, ${ }^{22}$ and the sole mononuclear one. It was isolated as a pale yellow solid. The $\mathrm{N}\left(\mathrm{SiMe}_{3}\right)_{2}{ }^{-}$amido moiety very typically imparts both kinetic stability and good solubility to the complex (it dissolves readily in organic solvents, including hydrocarbons). It is also sufficiently basic to open access to further organometallic derivatives (vide infra). A resonance at $\delta_{207 \mathrm{pb}} 2595 \mathrm{ppm}$ is seen in the ${ }^{207} \mathrm{~Pb} \mathrm{NMR}$ spectrum of 4 . Its molecular solid state structure was determined by single-crystal X-ray diffraction (Fig. 2). The metal is 3-coordinate with a distorted pyramidal geometry; the angles around the lead atom vary much, between $73.25(12)$ and $99.02(12)^{\circ}$. The $\mathrm{Pb} 1-\mathrm{N} 8$ interaction of the $N_{\text {amine }}$ in the pendant arm is stronger in $4(2.490(3) \AA)$ than in the 4-coordinate $\left[\left\{\mathrm{N}^{\wedge} \mathrm{C}\right\}_{2} \mathrm{~Pb}\right](2.616(3)-2.727(3) \AA)^{21},{ }^{21}$ but the $\mathrm{Pb}-\mathrm{C}$ interatomic distances in the two complexes are commensurate. The $\mathrm{Pb}-\mathrm{C}$ distance in $\mathbf{4}$ also compares well with those in four-coordinate $\mathrm{Pb}$ (II) complexes bearing a $\mathrm{O}^{\wedge} \mathrm{C}^{\wedge} \mathrm{O}$ pincer ligand. ${ }^{23}$ The $\mathrm{Pb} 1-\mathrm{N} 11$ interatomic distance

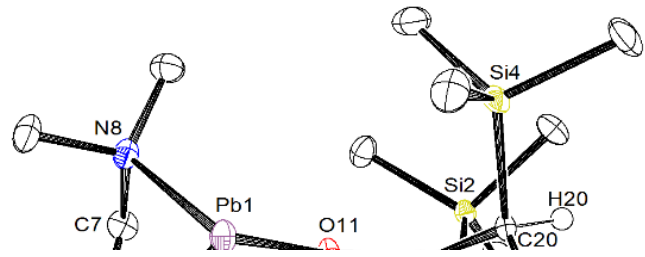

Fig. 3 ORTEP representation of the solid state structure of $\left[\left\{\mathrm{N}^{\wedge} \mathrm{C}\right\} \mathrm{PbOB}\left\{\mathrm{CH}\left(\mathrm{SiMe}_{3}\right)_{2}\right\}_{2}\right]$ (5). Ellipsoids drawn at the $50 \%$ probability level. Most $\mathrm{H}$ atoms omitted for clarity. Selected interatomic distances $(\AA)$ : Pb1-O11 $=2.1874(19), \mathrm{Pb} 1-\mathrm{C} 1=2.286(3), \mathrm{Pb} 1-\mathrm{N} 8$ $=2.467(2), \mathrm{O} 11-\mathrm{B} 12=1.340(4), \mathrm{B} 12-\mathrm{C} 13=1.607(4), \mathrm{B} 12-\mathrm{C} 20=1.609(4)$. Selected angles $\left({ }^{\circ}\right)$ : O11-Pb1-C1 = 89.25(9), O11-Pb1-N8 = 86.24(8), C1-Pb1-N8 = 73.37(9), $\mathrm{B} 12-\mathrm{O} 11-\mathrm{Pb} 1=136.46(18), \mathrm{O} 11-\mathrm{B} 12-\mathrm{C} 13=117.50(2), \mathrm{O} 11-\mathrm{B} 12-\mathrm{C} 20=125.30(2)$, $\mathrm{C} 13-\mathrm{B} 12-\mathrm{C} 20=117.20(2)$.
$(2.249(3) \AA)$ is characteristic for such 3 -coordinate lead(II) complexes. ${ }^{6}$

The reaction of 4 with equimolar $\left\{\left(\mathrm{Me}_{3} \mathrm{Si}\right)_{2} \mathrm{CH}\right\}_{2} \mathrm{BOH}$ does not release $\left\{\mathrm{N}^{\wedge} \mathrm{C}\right\} \mathrm{H}$. Instead, it proceeds to generate the very moisture- and air-sensitive, colourless heteroleptic boroxide $\left[\left\{\mathrm{N}^{\wedge} \mathrm{C}\right\} \mathrm{PbOB}\left\{\mathrm{CH}\left(\mathrm{SiMe}_{3}\right)_{2}\right\}_{2}\right]$ (5) through selective release of $\mathrm{HN}\left(\mathrm{SiMe}_{3}\right)_{2}$. The observed reactivity was unexpected on account of the respective basicity of the substituents on the metal $\left(p \mathrm{~K}_{\mathrm{a}}: \mathrm{HN}\left(\mathrm{SiMe}_{3}\right)_{2} / \mathrm{N}\left(\mathrm{SiMe}_{3}\right)_{2}{ }^{-}, 25.8 ; \mathrm{C}_{6} \mathrm{H}_{6} / \mathrm{C}_{6} \mathrm{H}_{5}{ }^{-}=43.0\right)$. Instead, it presumably reflects the greater covalent character of the $\mathrm{Pb}(\mathrm{II})-\mathrm{C}$ bond compared to the $\mathrm{Pb}(\mathrm{II})-\mathrm{N}$ one. The colourless 5 was isolated in a non-optimised $41 \%$ yield by recrystallisation from pentane. The complex exhibits a resonance at $\delta_{11 \mathrm{~B}} 48.1 \mathrm{ppm}$ in ${ }^{11} \mathrm{~B}$ NMR spectroscopy, i.e. it is shielded by ca. $5 \mathrm{ppm}$ compared to $\mathbf{1}$. This is assumed to reflect the greater electronic density at the metal centre in the 3-coordinate 5 . In the ${ }^{207} \mathrm{~Pb}$ NMR spectrum, a sole resonance is visible at $\delta_{207 \mathrm{pb}} 3095 \mathrm{ppm}$. The composition and structure of 5 were corroborated by XRD analysis. The environment about the 3-coordinate metal is trigonal pyramidal (Fig. 3). The $\mathrm{Pb} 1-\mathrm{N} 8$ and $\mathrm{Pb} 1-\mathrm{C} 1$ interatomic distances match those in 4. On the other hand, the Pb1-O11 contact $(2.1874(19) \AA)$ to $O_{\text {boroxide }}$ is longer than in $\mathbf{1}$. The angles around $\mathrm{Pb} 1$ in $\mathbf{5}$ are also substantially different from those in $\mathbf{4}$, i.e. they are narrower except for the matching $\mathrm{O}-\mathrm{Pb}-\mathrm{C}$ angles. The $\mathrm{B} 12-\mathrm{O} 11-\mathrm{Pb} 1$ angle in $5\left(136.46(18)^{\circ}\right)$ is also narrower than the pertaining B2-O1-Pb1 and B22-O21-Pb1 angles in 1 (147.90(5) and $\left.145.10(5)^{\circ}\right)$. Taken collectively, these data point at a lower participation of the $\pi$ lone pairs at 011 to the formation of the $\mathrm{Pb}-\mathrm{O}_{\text {boroxide }}$ bond in $\mathbf{5}$ than seen in $\mathbf{1}$. The geometry around the boron atom is perfectly trigonal planar $\left(\Sigma_{\theta}(B 12)=360.0^{\circ}\right)$. Note that 5 can also be prepared cleanly by mixing the homoleptic precursors $\left[\left\{\mathrm{N}^{\wedge} \mathrm{C}\right\}_{2} \mathrm{~Pb}\right]$ and $\mathbf{1}$ in equimolar amounts at room temperature.

The reactivity observed between 4 and $\left\{\left(\mathrm{Me}_{3} \mathrm{Si}\right)_{2} \mathrm{CH}\right\}_{2} \mathrm{BOH}$ and the stability of the resulting complex $\mathbf{5}$ both appear to be exceptional. Hence, all our attempts at preparing a congeneric alkoxide or siloxide of the type $\left[\left\{\mathrm{N}^{\wedge} \mathrm{C}\right\} \mathrm{PbOR}\right]$ met with failure. The reactions of $\left[\left\{\mathrm{N}^{\wedge} \mathrm{C}\right\}_{2} \mathrm{~Pb}\right]$ with $\left[\mathrm{Pb}\left(\mu^{2}-\mathrm{O}^{\mathrm{i}} \mathrm{Pr}\right)_{2}\right]_{\propto}$ or $\left[\mathrm{Pb}_{3}\left(\mu^{2}-\right.\right.$ $\left.\left.\left.\mathrm{O}^{\mathrm{t}} \mathrm{Bu}\right)\right\}_{6}\right]$ returned pure, unreacted starting materials. Moreover, no reaction took place between $\left[\left(\mathrm{N}^{\wedge} \mathrm{C}\right\} \mathrm{Li}\right]_{n}$ and the well soluble $\left.\left[\mathrm{Pb}_{3}\left(\mu^{2}-\mathrm{O}^{\mathrm{t}} \mathrm{Bu}\right)\right\}_{6}\right]$. Finally, $\left[\left\{\mathrm{N}^{\wedge} \mathrm{C}\right\}_{2} \mathrm{~Pb}\right]$ was the sole isolable product generated by treatment of 4 with ${ }^{\mathrm{t}} \mathrm{BuOH}$ or $\left(\mathrm{CF}_{3}\right)_{2} \mathrm{CHOH}$. The stability of 5 hence appears to stem from the combination of the bidentate $\left\{\mathrm{N}^{\wedge} \mathrm{C}\right\}^{-}$ligand and the bulky, "electron poor" boroxide.

In conclusion, the utilisation of the bulky ligand $\left\{\left(\mathrm{Me}_{3} \mathrm{Si}\right)_{2} \mathrm{CH}\right\}_{2} \mathrm{BO}^{-}$enables the facile syntheses of the first lead(II) boroxides, the homoleptic 2-coordinate $\left[\mathrm{Pb}\left(\mathrm{OB}\left\{\mathrm{CH}\left(\mathrm{SiMe}_{3}\right)_{2}\right\}_{2}\right)_{2}\right]$ (1) and the 3-coordinate, heteroleptic organolead(II) $\quad\left[\left\{\mathrm{N}^{\wedge} \mathrm{C}\right\} \mathrm{PbOB}\left\{\mathrm{CH}\left(\mathrm{SiMe}_{3}\right)_{2}\right\}_{2}\right] \quad$ (5). These compounds fill a loophole that hitherto existed in the coordination chemistry of lead and, more generally, group 14 metals. Although air-sensitive, $\mathbf{1}$ and $\mathbf{5}$ are stable in solution and in the solid state (a clean melting temperature of $141{ }^{\circ} \mathrm{C}$ was even determined for $\mathbf{5}$, although 1 decomposed between $110-130{ }^{\circ} \mathrm{C}$ to generate a dark red unidentified solid), and do 
not seem to generate the oxoclusters that have so often plagued the chemistry of more traditional lead(II) alkoxides and siloxides. We are now pursuing our efforts to understand the specificity of lead(II) boroxides, and we are also hoping to use these compounds to probe unchartered areas of organolead(II) chemistry.

\section{Conflicts of interest}

There are no conflicts to declare.

\section{Notes and references}

1 (a) W. H. Dumbaugh and J. C. Lapp, J. Am. Ceram. Soc., 1992 75, 2315; (b) S. Kohara, H. Ohno, M. Takata, T. Usuki, H. Morita, K. Suzuya, J. Akola and L. Pusztai, Phys. Rev. B, 2010, 82, 134209; (c) R. G. Fernandes, J. Ren, A. S. S. de Camargo, A. C. Hernandes and H. Eckert, J. Phys. Chem. C, 2012, 116 6434.

2 (a) R. Papiernik, L. G. Hubert-Pfalzgraf and M. C. Massiani, Inorg. Chim. Acta, 1989, 165, 1; (b) R. Papiernik, L. G. HubertPfalzgraf and M. C. Massiani, Polyhedron, 1991, 10, 1657.

3 S. C. Goel, M. Y. Chiang and W. E. Buhro, Inorg. Chem., 1990, 29, 4640 .

4 D. J. Teff, J. C. Huffman and K. G. Caulton, J. Am. Chem. Soc., 1996, 118, 4030.

5 L. Wang, S. Fadlallah, C. Bellini, C. Orione, V. Dorcet, J.-F. Carpentier and Y. Sarazin, Organometallics, 2015, 34, 1321.

6 A. Pop, L. Wang, V. Dorcet, T. Roisnel, J.-F. Carpentier, A. Silvestru and Y. Sarazin, Dalton Trans., 2014, 43, 16459.

7 (a) E. C. Y. Tam, N. C. Johnstone, L. Ferro, P. B. Hitchcock and J. R. Fulton, Inorg. Chem., 2009, 48, 8971; (b) E. C. Y. Tam, M. P. Coles, J. D. Smith and J. R. Fulton, Polyhedron, 2015, 85 284.

8 C. Gaffney, P. G. Harrison and T. J. King, J. Chem. Soc., Chem. Commun., 1980, 1251.

9 W. Patnode and F. C. Schmidt, J. Am. Chem. Soc., 1945, 67, 2272.

10 C. S. Weinert, I. A. Guzei, A. L. Rheingold and L. R. Sita, Organometallics, 1998, 17, 498.

11 M. P. Coles, Coord. Chem. Rev., 2016, 323, 52.

12 (a) K. J. Weese, R. A. Bartlett, B. D. Murray, M. M. Olmstead and P. P. Power, Inorg. Chem., 1987, 26, 2409; (b) G. Beck, P. B. Hitchcock, M. F. Lappert and I. A. MacKinnon, J. Chem. Soc., Chem. Commun., 1989, 1312; (c) V. C. Gibson, C. Redshaw, W. Clegg and M. R. J. Elsegood, Polyhedron, 1997, 16, 2637; (d) S. C. Cole, M. P. Coles and P. B. Hitchcock, Organometallics, 2004, 23, 5159.

13 (a) S. Luliński, I. Madura, J. Serwatowski and J. Zachara, Inorg. Chem., 1999, 38, 4937; (b) R. Anulewicz-Ostrowska, S. Luliński, E. Pindelska and J. Serwatowski, Inorg. Chem., 2002, 41, 2525; (c) S. J. Birch, S. R. Boss, S. C. Cole, M. P. Coles, R. Haigh, P. B. Hitchcock and A. E. H. Wheatley, Dalton Trans., 2004, 3568.

14 (a) L. Synoradzki, M. Bolesławski and J. Lewínski, J. Organomet. Chem., 1985, 284, 1; (b) R. Köster, Y.-H. Tsay, C. Krüger and J. Serwatowski, Chem. Ber., 1986, 119, 1174; (c) R. Anulewicz-Ostrowska, S. Luliński, J. Serwatowski and K. Suwińska, Inorg. Chem., 2000, 39, 5763; (d) V. C. Gibson, S. Mastroianni, A. J. P. White and D. J. Williams, Inorg. Chem. $2001,40,826$.

15 S. Al-Hashimi and J. D. Smith, J. Organomet. Chem., 1978, $153,253$.

16 T. Heidemann and S. Mathur, Eur. J. Inorg. Chem., 2014, 506.
17 M. J. Taylor, E. J. Coakley, M. P. Coles, H. Cox and J. R. Fulton, Organometallics, 2015, 34, 2515.

18 S. Suh and D. M. Hoffman, Inorg. Chem., 1996, 35, 6164

19 D. J. Teff, J. C. Huffman and K. G. Caulton, Inorg. Chem., $1997,36,4372$.

20 The structure of the hexanuclear $\left[\mathrm{Pb}_{6}\left(\mu^{3}-\mathrm{O}\right)_{4}\left(\mu^{3}-\mathrm{O}^{\mathrm{i}} \mathrm{Pr}\right)_{4}\right]$ is known, see: A. I. Yanovskii, N. Y. Turova, E. P. Turevskaya and Y. T. Struchkov, Koord. Khim., 1982, 8, 153. For the structure of the tetranuclear $\left[\mathrm{Pb}_{4}\left(\mu^{4}-\mathrm{O}\right)\left(\mu^{2}-\mathrm{OSiPh}_{3}\right)_{6}\right]$, see ref. 8

21 J. Bareš, V. Šourek, Z. Padělková, P. Meunier, N. Pirio, I. Císařová, A. Růžička and J. Holeček, Collect. Czech. Chem. Commun., 2010, 75, 121.

22 A. C. Filippou, N. Weidemann and G. Schnakenburg, Angew. Chem. Int. Ed., 2008, 47, 5799.

23 K. Jurkschat, K. Peveling and M. Schürmann, Eur. J. Inorg Chem., 2003, 3563. 